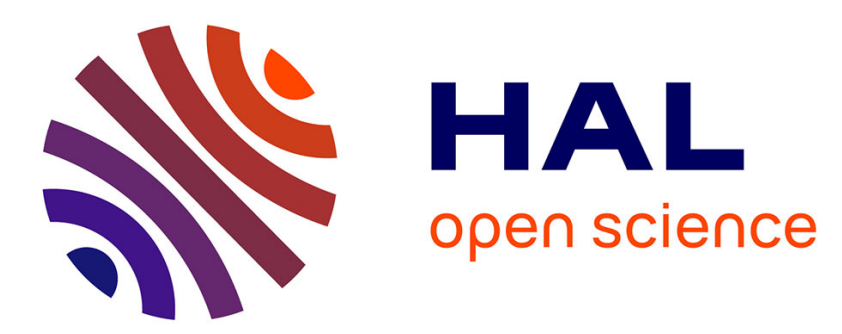

\title{
Structure of Ba2In2-xVxO5+x phases: complementarity of diffraction, Raman and absorption techniques
}

\author{
Aurélie Rolle, Sylvie Daviero-Minaud, Pascal Roussel, Annick Rubbens, \\ Rose-Noëlle Vannier
}

\section{- To cite this version:}

Aurélie Rolle, Sylvie Daviero-Minaud, Pascal Roussel, Annick Rubbens, Rose-Noëlle Vannier. Structure of Ba2In2-xVxO5+x phases: complementarity of diffraction, Raman and absorption techniques. Solid State Ionics, 2007, soumis, pp.xx-xx. hal-00187465

\section{HAL Id: hal-00187465 https://hal.science/hal-00187465}

Submitted on 14 Nov 2007

HAL is a multi-disciplinary open access archive for the deposit and dissemination of scientific research documents, whether they are published or not. The documents may come from teaching and research institutions in France or abroad, or from public or private research centers.
L'archive ouverte pluridisciplinaire HAL, est destinée au dépôt et à la diffusion de documents scientifiques de niveau recherche, publiés ou non, émanant des établissements d'enseignement et de recherche français ou étrangers, des laboratoires publics ou privés. 


\title{
Structure of $\mathrm{Ba}_{2} \mathrm{In}_{2-\mathrm{x}} \mathrm{V}_{\mathrm{x}} \mathrm{O}_{5+\mathrm{x}}$ phases: complementarity of diffraction, Raman and absorption techniques
}

\author{
A. Rolle, S. Daviero-Minaud, P. Roussel, A. Rubbens, R. N. Vannier \\ Equipe de Chimie du Solide - UCCS - Unité de Catalyse et Chimie du Solide - CNRS UMR \\ 8181, USTL-ENSCL, BP 90 108, 59652 Villeneuve d'Ascq Cedex, France \\ Email: Aurelie.Rolle@ensc-lille.fr
}

\section{Abstract}

By combining X-ray and neutron diffraction with Raman and X-ray absorption spectroscopies, the location of vanadium in the structure of the $\mathrm{Ba}_{2} \mathrm{In}_{2-\mathrm{x}} \mathrm{V}_{\mathrm{x}} \mathrm{O}_{5+\mathrm{x}}$ solid solution and its local environment was evidenced. Vanadium is spread over the two Indium sites of the Brownmillerite structure but its surrounding is tetrahedral. This involves the introduction of oxygen vacancies in the "octahedral" layers of $\mathrm{Ba}_{2} \mathrm{In}_{2} \mathrm{O}_{5}$ and the presence of Indium with a VI fold coordination in the "tetrahedral" layers. The number of InO octahedra increases with the substitution rate which explains the stabilisation of cubic forms for substitution rate higher than 0.3 .

Keywords: Brownmillerite, oxide ion conductor, barium oxide, indium oxide, $\mathrm{Ba}_{2} \operatorname{In}_{2} \mathrm{O}_{5}$, neutron diffraction, X-ray diffraction, X-ray absorption spectroscopy, Raman scattering

\section{Introduction}

Because of its oxide ion conduction properties, $\mathrm{Ba}_{2} \mathrm{In}_{2} \mathrm{O}_{5}$ has a potential of application as electrolyte for solid oxide fuel cells, oxygen generating systems or membrane for dense catalytic reactors [1-4]. At room temperature, it adopts the Brownmillerite structure. Its 
symmetry is orthorhombic and it can be described as a defective perovskite composed of alternating "octahedral" $\left(\operatorname{In}(1) \mathrm{O}_{6}\right)$ and "tetrahedral" $\left(\operatorname{In}(2) \mathrm{O}_{4}\right)$ layers. It can also be viewed as an oxygen-ordered-vacancy defect perovskite in which one-sixth of the oxygen ions of the perovskite structure is replaced by an ordered array of vacancies. When the temperature increases, the symmetry becomes tetragonal $\left(\mathrm{T}>925^{\circ} \mathrm{C}\right)$ and then cubic $\left(\mathrm{T}>1040^{\circ} \mathrm{C}\right)$. These high temperature forms are highly oxide ion conductive [2,3,5-9]. With the aim to stabilize these two polymorphs at lower temperatures, numerous substitutions on the indium site, on the barium site or on both sites were reported in the literature. Our group considered the partial substitution for indium with vanadium, molybdenum and tungsten [10]. Solid solutions were evidenced for the three dopants. For vanadium compounds, $\mathrm{Ba}_{2} \mathrm{In}_{2-\mathrm{x}} \mathrm{V}_{\mathrm{x}} \mathrm{O}_{5+\mathrm{x}}$, the solid solution limit was found in between $x=0.4$ and $x=0.5$. Its symmetry is orthorhombic for $0 \leq x$ $<0.2$, tetragonal for $\mathrm{x}=0.2$ and cubic for $\mathrm{x} \geq 0.3$. In the orthorhombic form, there are two possibilities of location for the dopant, in the octahedral or in the tetrahedral layers. Moreover, vanadium is known to easily adopt several coordinations, IV, V or VI and its actual surrounding is therefore not obvious. The determination of the dopant location in the vanadium solid solution and its local surrounding is the aim of this paper. In that frame, neutron diffraction, X-ray diffraction, Raman scattering and X-ray absorption spectroscopy were combined.

\section{Experimental}

The doped phases $\mathrm{Ba}_{2} \operatorname{In}_{2-\mathrm{x}} \mathrm{V}_{\mathrm{x}} \mathrm{O}_{5+\mathrm{x}}$ with $\mathrm{x}=0.1,0.2,0.3,0.4$ were prepared as described in [10]. The compositions were checked by Energy Dispersive Spectroscopy and found to be in very good agreement with the starting compositions.

The structure of composition $\mathrm{x}=0.1$ was refined by combining $\mathrm{X}$-ray and neutron diffraction data. X-ray diffraction data were collected at room temperature on a Bruker axs D8 
Advance diffractometer, equipped with a SolX energy dispersive detector, in the $5-100^{\circ}$ range $\left(\lambda_{\mathrm{CuK \alpha}}=1.5418 \AA\right)$ with a step of $0.02^{\circ}$. Neutron diffraction data were collected at room temperature on the high resolution powder diffractometer D2B at the Institut Laue Langevin (I.L.L.) at Grenoble. Approximately $20 \mathrm{~g}$ of compound were placed in a quartz tube open at one end and data were collected in the $0.3-130^{\circ}$ range with a step of $0.05^{\circ}$ at a wavelength of $1.594 \AA$ A. X-ray and neutron diffraction data were refined together using the beta version of JANA 2006 software, option powder [11]. The Rietveld method was applied.

Raman spectra were recorded at room temperature with the $647.1 \mathrm{~nm}$ excitation line from a Spectra Physics krypton ion laser. The beam was focused onto the sample using the macroscopic configuration of the apparatus. The scattered light was analyzed with an XY Raman Dilor spectrometer equipped with an optical multichannel charge coupled device liquid nitrogen -cooled detector. Acquisition and data processing were performed with the LABSPEC software.

X-ray absorption spectroscopy was performed at the Elettra Synchrotron in Trieste (Italy), on the BL 11.1 (XAFS) line with a Si (111) double monochromator, at the vanadium K edge $(5465 \mathrm{eV})$ and at the indium $\mathrm{L}_{\mathrm{I}}$ edge $(4237 \mathrm{eV})$. Indeed, for this later, the energy range of the Elettra Synchrotron does not make possible to reach the K edge. The XANES data were collected at the Vanadium $\mathrm{K}$ edge on fluorescence mode and in transmission mode at the Indium $\mathrm{L}_{\mathrm{I}}$ edge with a $0.2 \mathrm{eV}$ step and an integrating time of 3 seconds per step near the edges, and $1 \mathrm{eV}$ step further. In order to increase the signal quality, a minimum of 3 spectra were summed for each compound. For energy calibration, vanadium (energy range: 5450$5550 \mathrm{eV}$ ) and zinc (energy range: $9640-9690 \mathrm{eV}$ ) metal foils were used as references. The XANES spectra were normalized, after a linear subtraction of the pre-edge background absorption, to a value far enough from the absorption edge that coincides with a zero of the EXAFS signal. 


\section{Results and discussion}

\subsection{Dopant location in the Brownmillerite structure}

The structure was refined by combining X-ray and neutron diffraction data. The structural model of the $\mathrm{Ba}_{2} \mathrm{In}_{2} \mathrm{O}_{5}$ described in the Icmm space group was used. In this model, $\operatorname{In}(2)$ and $\mathrm{O}(3)$ are located in a (8i) site with a partial occupancy of 0.5 which allows two possible orientations for the tetrahedra in the $\operatorname{In}(2) \mathrm{O}$ layers as shown by TEM [12]. The wavelength of neutron being not accurate, it was refined with the unit cell parameters of this composition constrained to the value obtained from X-ray diffraction data. This led to a value of $\lambda=$ 1.5941(2) $\mathrm{A}$. The profiles were described by a pseudo-Voigt function and the backgrounds were determined manually. The result of the refinement is given in Table 1 . The observed, calculated diffraction patterns and the corresponding differences are reported in Fig. $1 \mathrm{a}$ and b. Vanadium was first introduced in both $\operatorname{In}(1)$ and $\operatorname{In}(2)$ sites with a constrain on their occupancy to verify the initial composition. Occupancies were refined in the last step of the refinement. A Fourier difference was calculated and revealed an extra oxygen position at (1/4, $1 / 4,1 / 4)$. This extra oxygen site was then introduced in the refinement and occupancies of all oxygen sites were refined with constrain: the sum of their occupancies had to be equal to the expected oxygen stoichiometry. The thermal motions of all atoms were described using anisotropic parameters. The refinement revealed that vanadium substitutes both sites with occupancies of $0.044(4)$ and $0.056(4)$ in the $\operatorname{In}(1)$ (octahedral layers) and $\operatorname{In}(2)$ (tetrahedral layers) sites, respectively. Vacancies are also to be noticed in the $\mathrm{O}(1)$ and $\mathrm{O}(2)$ oxygen sites whereas the $\mathrm{O}(3)$ oxygen site is fully occupied. Interestingly, although these numbers must be taken with care because of the accuracy, the refinement led to the same amount of oxygen vacancy in the $\mathrm{O}(1)$ site (equatorial site of the octahedral $\mathrm{InO}$ layers), as vanadium in the $\operatorname{In}(1)$ site. 


\subsection{Local environment of metal in the structure}

\subsubsection{Raman spectroscopy}

To define the local environment of vanadium in the structure, Raman scattering was performed on several compositions, $\mathrm{x}=0, \mathrm{x}=0.1, \mathrm{x}=0.2$ and $\mathrm{x}=0.3$. The spectra were compared to those of references carefully chosen for the different surrounding of vanadium and indium: $\mathrm{Ba}_{3}\left(\mathrm{VO}_{4}\right)_{2}$ in which the vanadium environment is composed of isolated tetrahedra, $\mathrm{V}_{2} \mathrm{O}_{5}$ whose structure is built upon square pyramids and $\operatorname{In}_{2} \mathrm{O}_{3}$ in which indium has an irregular octahedral environment. These spectra are given in Fig. 2. $\mathrm{Ba}_{3}\left(\mathrm{VO}_{4}\right)_{2}$ exhibits four bands at $837,780,380$ and $328 \mathrm{~cm}^{-1}$ which are typical of tetrahedral $\mathrm{VO}_{4}$ species [13]. These bands are also found in the substituted compounds at the same frequency values. However, they are broadened. The broadening increases with the substitution rate, it is characteristic of disorder. A tetrahedral surrounding for vanadium is confirmed by the bands observed in the $250-400$ $\mathrm{cm}^{-1}$ frequency range which are assigned to angular deformations of the $\mathrm{VO}_{4}$ entity. For an octahedral environment, bands at frequency above $900 \mathrm{~cm}^{-1}$ would be expected [14], which is not the case. The absence of lines around $996 \mathrm{~cm}^{-1}$ as observed for $\mathrm{V}_{2} \mathrm{O}_{5}$ excludes the possibility of square pyramids. These observations are therefore in agreement with a tetrahedral geometry for vanadium in different oxygen environments. One can also noticed a decrease in intensity of the most important band observed at $605 \mathrm{~cm}^{-1}$ for $\mathrm{Ba}_{2} \mathrm{In}_{2} \mathrm{O}_{5}$. This band could be assigned to stretching motions of the tetrahedral $\mathrm{InO}_{4}$ group since no such line is observed for $\operatorname{In}_{2} \mathrm{O}_{3}$. However, the response of indium oxides is far lower than that of vanadium oxides and one can not conclude on the indium environment from Raman spectroscopy only.

\subsubsection{XAFS spectroscopy}

To confirm the local surrounding of the dopant and to characterise the evolution of the Indium environment according to the substitution rate, XAFS experiments were performed. 
From these experiments, the oxidation number of these elements was also confirmed A few X-ray absorption spectroscopy studies have already been reported on $\mathrm{Ba}_{2} \operatorname{In}_{2} \mathrm{O}_{5}$ type compounds. Uchimoto et al. [15, 16] and Yao et al. [17] carried out EXAFS studies at the indium $\mathrm{K}$ edge on gallium and gadolinium doped compounds. The partial substitution of the barium site with lanthanum was also considered [18]. To our knowledge, no XAFS analysis on other doped compounds was reported in the literature. Here, the experiments were carried out at the vanadium $\mathrm{K}$ edge and at the indium $\mathrm{L}_{\mathrm{I}}$ edge to provide information on their local environment geometry and valence.

\subsubsection{The vanadium $K$ edge}

Through the study of the characteristic pre-edge involved in the $1 \mathrm{~s} \rightarrow 3 \mathrm{~d}$ transition, XANES data can give qualitative information on the site symmetry. Indeed, this transition is forbidden in a regular octahedral symmetry, but becomes possible for irregular sites. The most intense pre-edge is then observed for tetrahedral symmetry.

Experiments were performed on $\mathrm{Ba}_{2} \mathrm{In}_{2-\mathrm{x}} \mathrm{V}_{\mathrm{x}} \mathrm{O}_{5+\mathrm{x}}$ with $\mathrm{x}=0.1$ (orthorhombic), $\mathrm{x}=0.2$ (tetragonal), $\mathrm{x}=0.3$ (cubic) and $\mathrm{x}=0.4$ (cubic). Crystallised reference compounds were carefully selected according to their well characterized vanadium environment and valence: $\mathrm{Ba}_{3}\left(\mathrm{VO}_{4}\right)_{2}\left(\mathrm{~V}^{\mathrm{V}}\right)$ in which the vanadium environment is composed of isolated tetrahedra and $\mathrm{VOSO}_{4}\left(\mathrm{~V}^{\mathrm{IV}}\right)$ where the vanadium is in a distorted octahedral environment.

As shown in Fig. 3a, the spectra of the substituted compounds are almost the same. They are characterised by the existence of an intense pre-edge nearly as high as $\mathrm{Ba}_{3}\left(\mathrm{VO}_{4}\right)_{2}$ one and at the same energy. This confirms the Raman results. In the substituted compounds, the vanadium environment is therefore mainly tetrahedral, which is consistent with the presence of vacancies in the octahedral layer. Their edge position is similar to that of $\mathrm{Ba}_{3}\left(\mathrm{VO}_{4}\right)_{2}$, the valence of the vanadium in these compounds is then equal to $\mathrm{V}$. 


\subsubsection{The indium $L_{I}$ edge}

The XAFS spectra at $\mathrm{L}_{\mathrm{I}}$ edge were recorded on $\mathrm{Ba}_{2} \mathrm{In}_{2-\mathrm{x}} \mathrm{V}_{\mathrm{x}} \mathrm{O}_{5+\mathrm{x}}$ compositions with $\mathrm{x}=0.1$ (orthorhombic) and $\mathrm{x}=0.3$ (cubic). The selected crystallised references were $\mathrm{Ba}_{2} \mathrm{In}_{2} \mathrm{O}_{5}$ in which the indium atom has in octahedral and tetrahedral environment and $\operatorname{In}_{2} \mathrm{O}_{3}$ where it has an irregular octahedral environment. The XANES signal obtained at the indium $\mathrm{L}_{\mathrm{I}}$ edge for doped compounds is similar to $\mathrm{Ba}_{2} \mathrm{In}_{2} \mathrm{O}_{5}$ one (Fig. 3b): the indium atom has a mixed octahedral-tetrahedral environment. However, the intensity of the edge increases with the substitution rate and becomes closer to $\mathrm{In}_{2} \mathrm{O}_{3}$ one which supports an increase of octahedral environment for indium when the substitution rate increases.

Whatever the substitution rate, the indium atom has a more octahedral medium environment than in the undoped $\mathrm{Ba}_{2} \mathrm{In}_{2} \mathrm{O}_{5}$. This is in good agreement with the tetrahedral environment of the vanadium described previously. Indeed as the vanadium environment is tetrahedral, the number of indium atoms having an octahedral environment has to increase, all the more than the partial substitution with vanadium implies the introduction of additional oxide ions.

\section{Conclusions}

By combining X-ray and neutron diffraction with Raman and X-ray absorption spectroscopies, the location of vanadium in the structure of the $\mathrm{Ba}_{2} \operatorname{In}_{2-\mathrm{x}} \mathrm{V}_{\mathrm{x}} \mathrm{O}_{5+\mathrm{x}}$ solid solution and its local environment was evidenced. Vanadium is spread over the two Indium sites of the Brownmillerite structure but its surrounding is tetrahedral. This involves the introduction of oxygen vacancies in the "octahedral" layers of $\mathrm{Ba}_{2} \operatorname{In}_{2} \mathrm{O}_{5}$ and the presence of Indium with a VI fold coordination in the "tetrahedral" layers. The number of InO octahedra increases with the substitution rate which explains the stabilisation of cubic forms for substitution rate higher than 0.3. 


\section{Acknowledgements}

The Institut Laue Langevin is thanked for providing neutron facilities and Dr. Emmanuelle Suard (Institut Laue Langevin) is gratefully acknowledged for helpful discussions. Dr Belin (local contact on an EXAFS line - ex Lure, Soleil, France) and Dr Olivi (local contact on an EXAFS line - Elettra, Trieste, Italy) are acknowledged for their help and availability. The authors are very grateful to L. Burylo for X-ray diffraction. The «Fonds Européen de Développement Régional (FEDER) », the «Centre National de la Recherche Scientifique » (CNRS), the « Région Nord Pas-de-Calais » and the «Ministère de l'Education Nationale, de l'Enseignement Supérieur et de la Recherche» are acknowledged for fundings of X-ray

diffractometers. A. R. is grateful to the CNRS and the «Région Nord Pas-de-Calais » for the funding of her $\mathrm{PhD}$ grant. V. Petricek is acknowledged for providing us the JANA 2006 beta Version allowing the combined refinement of X-ray and neutron data

\section{References}

[1] D. H. Gregory, M. T. Weller, J. Solid State Chem. 107 (1) (1993) 134.

[2] S. B. Adler, J. A. Reimer, J. Baltisberger, U. Werner, J. Am. Chem. Soc. 116 (1994) 675.

[3] S. A. Speakman, J. W. Richardson, B. J. Mitchell, S. T. Misture, Solid State Ionics 149 (2002) 247.

[4] J.B. Goodenough, J.E. Ruiz-Diaz, Y.S Zhen, Solid State Ionics 44 (1990) 21.

[5] T. R. S. Prasanna, A. Navrotsky, J. Mater. Res. 8 (1993) 1484.

[6] G. B. Zhang, D. M. Smyth, Solid State Ionics 82 (1995) 161.

[7] M. Kanzaki, A. Yamaji, Mater. Sci. and Eng. B41 (1996) 46.

[8] T. Hashimoto, Y. Ueda, M. Yoshinaga, K. Komazaki, K. Asaoka and S. Wang, J. Electrochem. Soc. 149 (2002) 1381. 
[9] T. Hashimoto, K. Asaoka, K. Komazaki, Y. Ueda, M. Yoshinaga, Electrochemical Society Proceedings 28 (2001) 291.

[10] A. Rolle, R. N. Vannier, N. V. Giridharan, F. Abraham, Solid State Ionics 176 (2005) 2095.

[11] V. Petricek, M. Dusek, L. Palatinus, The crystallographic computing system JANA 2006 beta version, Institute of Physics, Praha, Czech Republic, 2007.

[12] P. Berastegui, S. Hull, F.J. Garcia-Garcia, S.G. Erikson, J. Solid State Chem. 164 (2002) 119.

[13] A. Lorriaux-Rubbens, J. Corset, J. Ghamri, H. Baussart, Ad. Mater. Research, Vols 1-2 (1994) 433.

[14] R.L. Frost, K.L. Erickson, M.L. Weier, O. Carmody, Spectrochim. Acta, A61 (2005) 829.

[15] Y. Uchimoto, M. Kinuhate, T. Yao, Japanese Journal of Applied Physics 38 (1998) 111, International Conference Synchotron Radiation in Materials Science SRMS-2, Kobe, Japan.

[16] Y. Uchimoto, M. Kinuhata, H. Takagi, T. Yao, T. Inagaki, H. Yoshida, Electrochemical Society 19 (1999) 317.

[17] T. Yao, Y. Uchimoto, M. Kinuhata, T. Inagaki, H. Yoshida, Solid State Ionics 132 (2000) 189.

[18] Y. Uchimoto, H. Takagi, T. Yao, N. Ozawa, T. Inagaki, H. Yashida, Journal of Synchrotron Radiation 8 (2001) 857. 


\section{Table captions}

Table 1. Structural model described in the space group Icmm deduced from the combined refinement of neutron diffraction and X-ray diffraction data corresponding to $\mathrm{Ba}_{2} \mathrm{In}_{2-\mathrm{x}} \mathrm{V}_{\mathrm{x}} \mathrm{O}_{\mathrm{x}}$ with $\mathrm{x}=0.1$ at room temperature.

\section{Tables}

Table 1. Structural model described in the space group Icmm deduced from the combined refinement of neutron diffraction and X-ray diffraction data corresponding to $\mathrm{Ba}_{2} \operatorname{In}_{2-\mathrm{x}} \mathrm{V}_{\mathrm{x}} \mathrm{O}_{\mathrm{x}}$ with $\mathrm{x}=0.1$ at room temperature.

\begin{tabular}{|c|c|c|c|c|c|}
\hline $\mathrm{a}(\AA)$ & $\mathrm{b}(\AA)$ & $\mathrm{c}(\AA)$ & \multicolumn{2}{|c|}{ volume $\left(\AA^{3}\right)$} & density \\
\hline $6.0564(3)$ & $16.8085(9)$ & 5.9698 & (3) & $72(8)$ & $6.33(6)$ \\
\hline atom site & $\mathrm{X}$ & $\mathrm{y}$ & $\mathrm{Z}$ & occupancy & $\mathrm{U}_{\mathrm{eq}}{ }^{*}\left(\AA^{2}\right)$ \\
\hline $8(h)$ & $0.5081(4)$ & $.61103(9)$ & 0 & 1 & $0.0101(8)$ \\
\hline $\begin{array}{ll}\operatorname{In}(1) & 4(a)\end{array}$ & 0 & 0 & 0 & $0.956(4)$ & $0.011(1)$ \\
\hline $\mathrm{V}(1) \quad 4(\mathrm{a})$ & 0 & 0 & 0 & $0.044(4)$ & $0.011(1)$ \\
\hline $\operatorname{In}(2) \quad 8(i)$ & $0.5519(4)$ & 0.25 & 0.5 & $0.944(4)$ & $0.011(1)$ \\
\hline $\begin{array}{ll}\mathrm{V}(2) & 8(\mathrm{i})\end{array}$ & $0.5519(4)$ & 0.25 & 0.5 & $0.056(4)$ & $0.011(1)$ \\
\hline $\mathrm{O}(1) \quad 8(\mathrm{~g})$ & 0.25 & $0.9942(2)$ & 0.25 & $0.978(4)$ & $0.0132(9)$ \\
\hline $\mathrm{O}(2) \quad 8(\mathrm{~h})$ & $0.0466(6)$ & $0.1379(2)$ & 0 & $0.986(6)$ & $0.029(1)$ \\
\hline $\mathrm{O}(3)$ & $0.6374(4)$ & 0.25 & $0.1382(1)$ & 0.5 & $0.038(3)$ \\
\hline $\mathrm{O}(4) \quad 4(\mathrm{c})$ & 0.25 & 0.25 & 0.25 & $0.17(2)$ & $0.038(3)$ \\
\hline
\end{tabular}

\begin{tabular}{ccccccc}
\hline$*$ & $\mathrm{U}_{11}$ & $\mathrm{U}_{22}$ & $\mathrm{U}_{33}$ & $\mathrm{U}_{12}$ & $\mathrm{U}_{13}$ & $\mathrm{U}_{23}$ \\
\hline $\mathrm{Ba}$ & $0.020(2)$ & $0.01(1)$ & $0.001(1)$ & $0.002(2)$ & 0 & 0 \\
\hline $\mathrm{In}(1)$ & $0.012(2)$ & $0.012(2)$ & $0.008(2)$ & $0.004(2)$ & 0 & 0 \\
\hline $\mathrm{V}(1)$ & $0.012(2)$ & $0.012(2)$ & $0.008(2)$ & $0.004(2)$ & 0 & 0 \\
\hline $\mathrm{In}(2)$ & $0.012(2)$ & $0.012(2)$ & $0.008(2)$ & $0.004(2)$ & 0 & 0 \\
\hline $\mathrm{V}(2)$ & $0.012(2)$ & $0.124(2)$ & $0.008(2)$ & $0.004(2)$ & 0 & 0 \\
\hline $\mathrm{O}(1)$ & $0.024(2)$ & $0.013(2)$ & $0.003(1)$ & 0 & $0.003(1)$ & 0 \\
\hline $\mathrm{O}(2)$ & $0.047(3)$ & $0.018(1)$ & $0.021(2)$ & $0.011(2)$ & 0 & 0 \\
\hline $\mathrm{O}(3)$ & $0.041(5)$ & $0.031(4)$ & $0.040(5)$ & 0 & $0.008(3)$ & 0 \\
\hline $\mathrm{O}(4)$ & $0.041(5)$ & $0.031(4)$ & $0.040(5)$ & 0 & $0.008(3)$ & 0 \\
\hline
\end{tabular}




\section{Figure Captions}

Fig. 1: a- Neutron diffraction pattern data and b- X-ray diffraction pattern, corresponding to $\mathrm{Ba}_{2} \mathrm{In}_{2-\mathrm{x}} \mathrm{V}_{\mathrm{x}} \mathrm{O}_{5+3 \mathrm{x} / 2}$ with $\mathrm{x}=0.1$, collected at room temperature

Fig. 2: Raman spectra of $\mathrm{Ba}_{2} \mathrm{In}_{2} \mathrm{O}_{5}(\mathrm{a}), \mathrm{In}_{2} \mathrm{O}_{3}(\mathrm{~b}), \mathrm{Ba}_{2} \mathrm{In}_{2-\mathrm{x}} \mathrm{V}_{\mathrm{x}} \mathrm{O}_{5+\mathrm{x}}: \mathrm{x}=0.1$ (c), $\mathrm{x}=0.2$ (d), $\mathrm{x}=$ 0.3 (e), $\mathrm{Ba}_{3}\left(\mathrm{VO}_{4}\right)_{2}$ (f) and $\mathrm{V}_{2} \mathrm{O}_{5}(\mathrm{~g})$.

Fig.3: a- XANES spectra at $\mathrm{K}$ edge of $\mathrm{Ba}_{2} \mathrm{In}_{2-\mathrm{x}} \mathrm{V}_{\mathrm{x}} \mathrm{O}_{5+\mathrm{x}}$ with $\mathrm{x}=0.1$ (orthorhombic), $\mathrm{x}=0.4$ (cubic) compared to $\mathrm{Ba}_{3}\left(\mathrm{VO}_{4}\right)_{2}$ and $\mathrm{VOSO}_{4}$ which are characterised by isolated tetrahedra and distorded octahedra, respectively, b- XANES spectra at $\mathrm{L}_{\mathrm{I}}$ edge $\mathrm{Ba}_{2} \mathrm{In}_{2-\mathrm{x}} \mathrm{V}_{\mathrm{x}} \mathrm{O}_{5+\mathrm{x}}$ compounds with $\mathrm{x}=0.1$ (orthorhombic), $\mathrm{x}=0.4$ (cubic) compared to $\operatorname{In}_{2} \mathrm{O}_{3}$ and $\mathrm{Ba}_{2} \mathrm{In}_{2} \mathrm{O}_{5}$ references, in which the indium has respectively an irregular environment and a mixed octahedral-tetrahedral environment. 


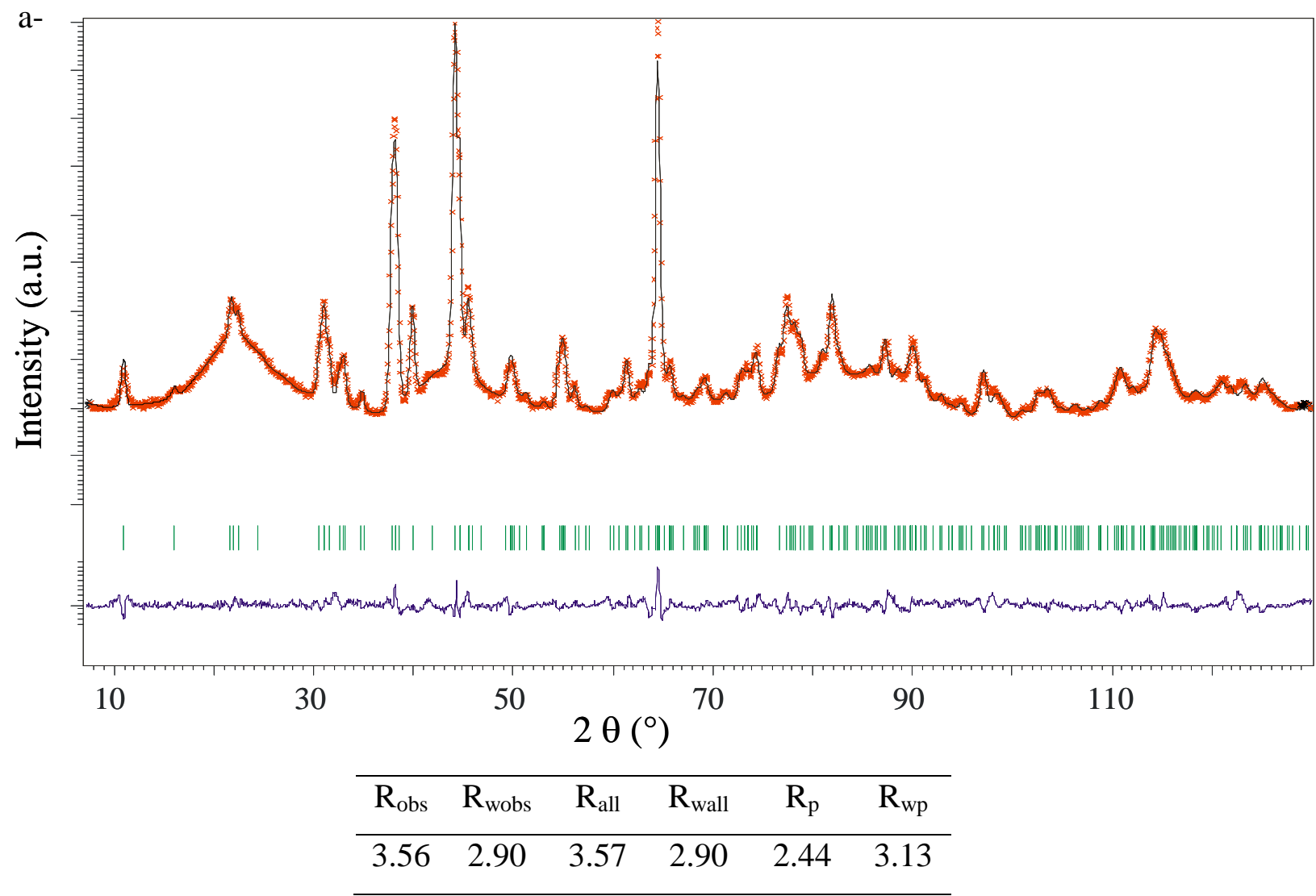

b-

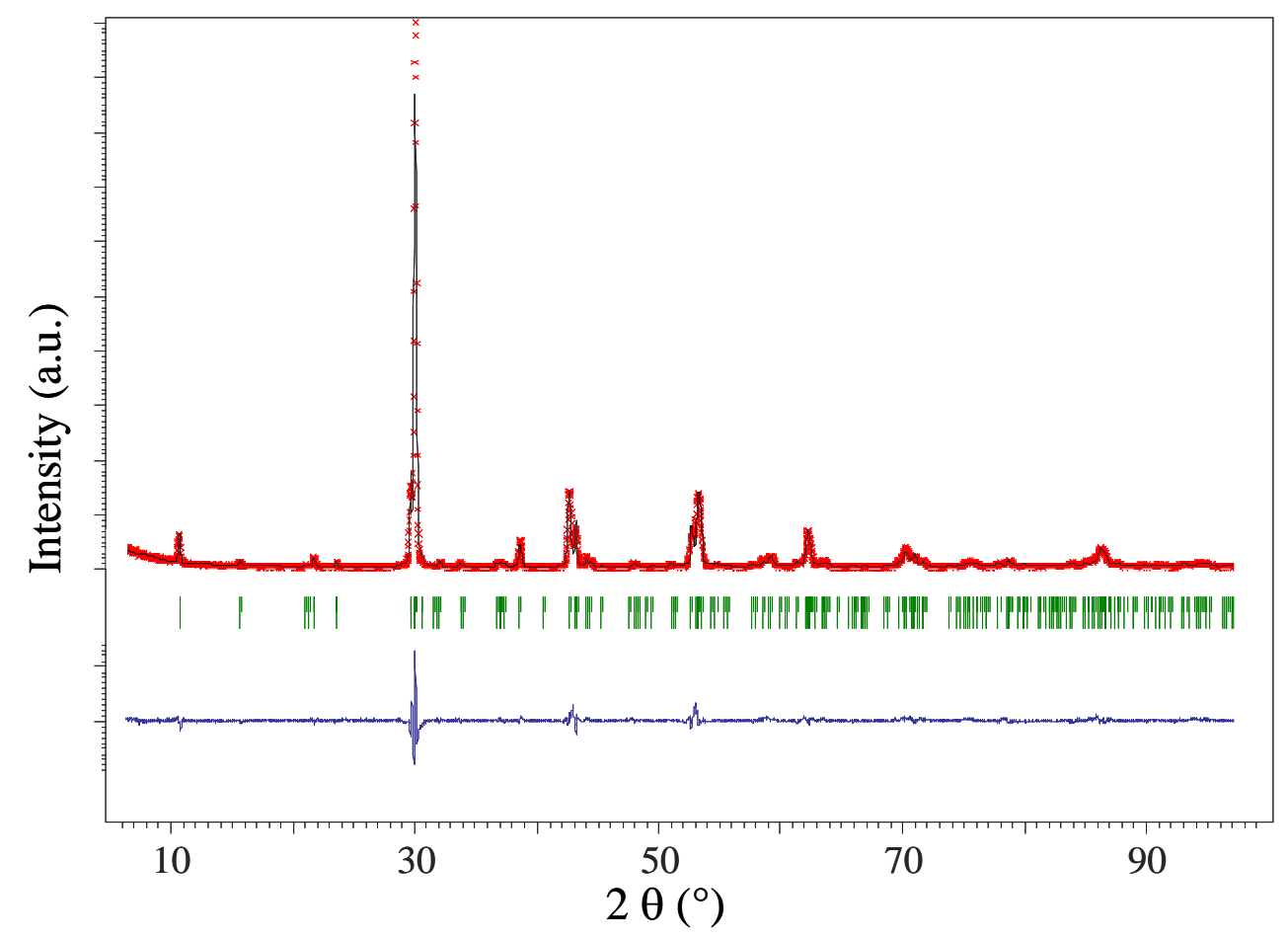

\begin{tabular}{cccccc}
\hline $\mathrm{R}_{\text {obs }}$ & $\mathrm{R}_{\text {wobs }}$ & $\mathrm{R}_{\text {all }}$ & $\mathrm{R}_{\text {wall }}$ & $\mathrm{R}_{\mathrm{p}}$ & $\mathrm{R}_{\mathrm{wp}}$ \\
\hline 6.49 & 4.61 & 6.84 & 4.62 & 12.81 & 16.67
\end{tabular}

Fig. 1. 


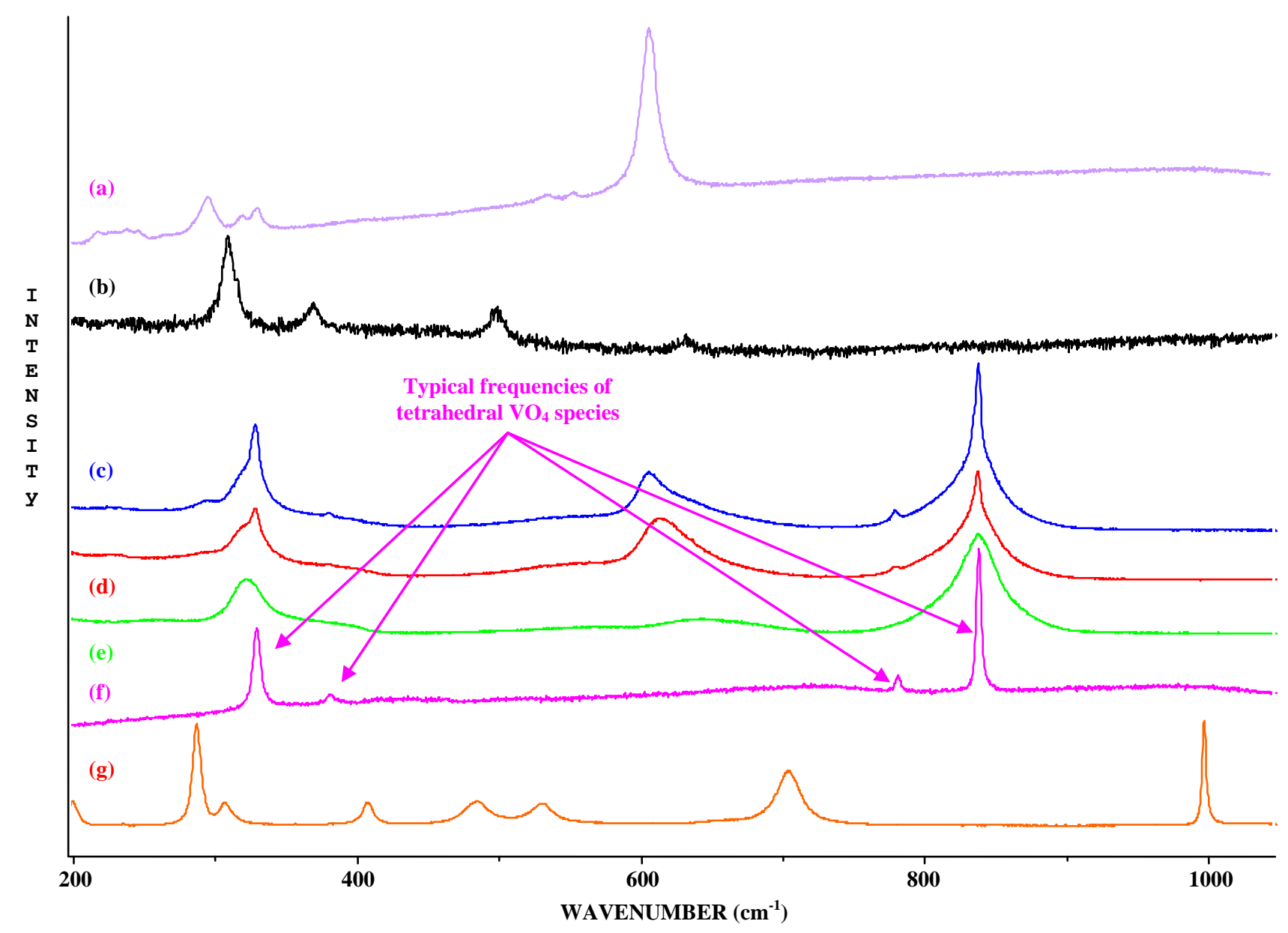

Fig. 2. 

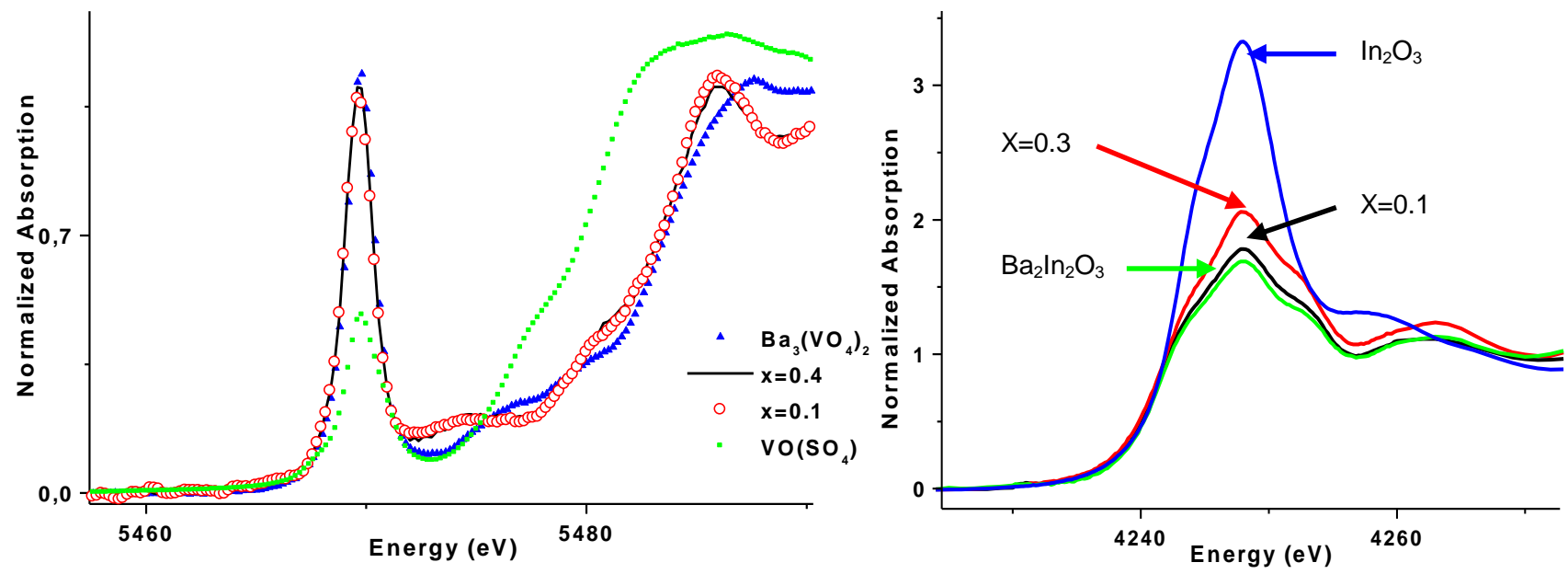

Fig.3. 